\title{
Sprawozdanie z konferencji naukowej „Dialog bez barier. Skuteczna komunikacja w kontekście EBP - praktyki opartej na dowodach" (Katowice, 8 czerwca 2019)
}

\begin{abstract}
A Report from the Academic Conference „Dialog bez barier. Skuteczna komunikacja w kontekście EBP - praktyki opartej na dowodach" (Katowice, 8 June 2019)
\end{abstract}

Konferencja naukowa „Dialog bez barier. Skuteczna komunikacja w kontekście EBP [Evidence-Based Practice] - praktyki opartej na dowodach" odbyła się 8 czerwca 2019 roku w Centrum Informacji Naukowej i Bibliotece Akademickiej (CıNiBA). Była ona współorganizowana przez Instytut Języka Polskiego im. Ireny Bajerowej, CINiB-ę, Fundację Wiedzy i Dialogu Społecznego „Agere Aude” oraz Koło Naukowe Młodych Logopedów Uniwersytetu Śląskiego w Katowicach. Konferencja została poświęcona zagadnieniom związanym z szeroko pojętą komunikacją, jej usprawnianiem oraz zaburzeniami poprawności jej przebiegu. Prelegenci, w tym między innymi przedstawiciele Uniwersytetu Śląskiego w Katowicach, Państwowej Wyższej Szkoły Filmowej, Telewizyjnej i Teatralnej w Łodzi oraz goście z zagranicznych uczelni (Uniwersytetu Leibniza w Hanowerze w Niemczech oraz brytyjskiego University of Sheffield), zaprezentowali zgromadzonemu audytorium referaty, stanowiące różnorodne ujęcia zagadnień, sygnalizowanych w tytule konferencji.

Wydarzenie rozpoczęło się uroczystym powitaniem przybyłych prelegentów oraz słuchaczy przez przedstawicielki organizacji zaangażowanych $w$ przygotowanie konferencji reprezentującą Instytut Języka Polskiego Ewę Ficek oraz przedstawicielkę CINiB-y, Katarzynę Wyszyńską. Dalej spotkanie zostało podzielone na cztery sesje. Podczas kolejnych trzech prelegentki i prelegenci wygłaszali półgodzinne referaty, dające możliwość spojrzenia na tematykę komunikacji z różnorodnych perspektyw - między innymi językoznawczej, logopedycznej oraz związanej z dydaktyką języków obcych czy bilingwizmem. Charakter ostatniej sesji był natomiast odmienny - podczas jej trwania uczestnicy mogli wziąć udział $w$ premierowej projekcji filmu When I Stutter - Kiedy się jąkam, poświęconego tematyce tego zaburzenia płynności mowy. Mogli też wysłuchać wywiadu z twórcami obrazu.

Podczas pierwszej z sesji, moderowanej przez Katarzynę Węsierską, referaty wygłosiły kolejno trzy prelegentki reprezentujące Uniwersytet Śląski w Katowicach. Pierwsza z nich, Kamila Kuros-Kowalska, w swoim wystąpieniu zatytułowanym Opóźniony rozwój mowy a nowe technologie poruszyła tematykę związaną z korzyściami, a przede wszystkim zagrożeniami, jakie niosą z sobą zdobycze techniki w odniesieniu do rozwoju mowy dziecka, przedstawiając argumenty zarówno za stosowaniem nowoczesnych technologii przez najmłodszych, jak i przeciw takiej możliwości. Następnie prelegentka przedstawiła wyniki 
badania, przeprowadzonego z udziałem grup dzieci: z opóźnionym oraz z prawidłowym rozwojem mowy. Miało ono na celu odniesienie przebiegu rozwoju ich mowy do częstotliwości użytkowania urządzeń multimedialnych. Uzyskane wyniki wyraźnie wskazywały na niekorzystny wpływ nadużywania elektroniki na różne aspekty rozwoju dziecka, w tym także rozwój interakcji społecznych. Kolejny referat, wygłoszony przez Ewę Ficek, nosił tytuł Drugie oblicze terapii? Czyli dialog terapeutyczny okiem językoznawcy/dyskursologa (i nie tylko). W swoim wystąpieniu prelegentka analizowała między innymi kwestie barier komunikacyjnych, które mogą zaistnieć podczas terapii, przedstawiła słuchaczom różne ujęcia i przykłady takiego procesu, z którymi mogli zetknąć się w wielu publikacjach oraz, co dla wielu niespodziewane, w popularnych programach telewizyjnych, takich, jak Big Brother czy Kuchenne Rewolucje. Jako ostatnia podczas pierwszego z paneli wystąpiła Ewa Biłas-Pleszak, wygłaszając referat zatytułowany W stronę komunikacji otwartej - o coachingu, mentoringu, tutoringu i innych niebezpiecznych rzeczach, w ramach którego przybliżyła audytorium różnorodne techniki i metody, które, stosowane zarówno w życiu prywatnym, jak i zawodowym, mogą znacząco usprawnić komunikację międzyludzką. Jego część poświęciła także zagadnieniu wprowadzania zmian, będących istotnym impulsem do rozwoju człowieka i do inicjowania różnego rodzaju przełomów w jego życiu, często jawiących się jako tytułowe niebezpieczne rzeczy, wdrażanie ich bowiem zwykle wiąże się z ryzykiem i narażaniem się na krytykę, jednak, jak zaznaczyła prelegentka, niepodejmowanie takich działań w związku z różnymi obawami znacznie ogranicza nasze możliwości i zawęża horyzonty.

Znaczną część drugiej z sesji, moderowanej przez Ewę Ficek, stanowiły referaty zagranicznych gości. Jako pierwsza wystąpiła reprezentująca niemiecki Uniwersytet Leibniza w Hanowerze Aleksandra Syczewska, absolwentka logopedycznych studiów licencjackich oraz tego kierunku studiów magisterskich na uniwersytecie w Niemczech, a obecnie doktorantka hanowerskiego uniwersytetu. Jej wystąpienie, noszące tytuł Terapia bilingwalna dzieci polsko-niemieckich z SLI na przykładzie zdolności narracyjnych, zostało poświęcone prezentacji i analizie wyników badań, przeprowadzanych $w$ ramach pracy doktorskiej, których celem było wskazanie, czy możliwa jest praca terapeutyczna z bilingwalnym dzieckiem zmagającym się ze specyficznymi zaburzeniami językowymi równocześnie $w$ obu znanych mu językach, kładąc przy tym nacisk na wspomniane umiejętności narracyjne, które zwykle u dzieci z SLI wymagają odpowiedniej stymulacji. Jak wykazało owo badanie, takie działanie jest dobrze przyjmowane przez uczestników terapii i przynosi zadowalające rezultaty. Następnie Marta Węsierska z Uniwersytetu w Sheffield zaprezentowała wyniki swoich badań, których celem było porównanie postaw polskich i brytyjskich studentów logopedii wobec giełkotu - tzw. mowy bezładnej, zaburzenia płynności mowy, charakteryzującego się jej zbyt szybkim i nieregularnym tempem, na temat którego wiedza, nawet wśród osób związanych z tematyką logopedyczną, wciąż bywa niewystarczająca. Wynik badania, uzyskany dzięki uzupełnieniu przez polskich i brytyjskich uczestników kwestionariusza badania opinii publicznej POSHA-Cl (Public Opinion Survey of Human Attributes - Cluttering) potwierdził ów stan rzeczy, wykazując, że poziom wiedzy i kompetencji polskich studentów jest nieco niższy w porównaniu do brytyjskiej grupy badawczej. Podczas panelu wspólnie wystąpiły także Aleksandra Boroń, logopeda-praktyk, prowadząca prywatne gabinety $w$ Sycowie i Zgorzelcu, oraz Karolina Wytrych, studentka Uniwersytetu Śląskiego w Katowicach - specjalności logopedycznej na kierunku komunikacja promocyjna 
i kryzysowa. Podczas wystąpienia, noszącego tytuł Sukces $w$ terapii jąkania - opinie „podwójnych" ekspertów, prelegentki rozważały, co oznacza ów sukces i dla osoby jąkającej się, i dla prowadzącego terapię, jakie czynniki są niezbędne do jego odniesienia i utrzymania zadowalającego efektu. Następnie przedstawiły one wyniki badania ankietowego, którego respondentami byli tzw. podwójni eksperci - osoby będące specjalistami w zakresie zaburzeń płynności mowy zarówno ze względu na swoje wykształcenie oraz praktykę zawodową, jak i osobiste doświadczenia związane z jąkaniem się, a także czynny udział $w$ działalności grup samopomocowych, również $w$ roli liderów. Respondenci $w$ ramach badania zostali poproszeni o spojrzenie na powyższe zagadnienie sukcesu terapeutycznego zarówno z perspektywy biorącego udział $w$ terapii klienta, jak i prowadzącego ją logopedy-terapeuty. Dzięki temu mogli oni tym skuteczniej zdefiniować oczekiwania, cele oraz wyznaczniki skuteczności terapii jąkania. Po tej serii referatów ponownie wyznaczony został czas na zadawanie pytań i dyskusję.

Następnie rozpoczęła się sesja trzecia, moderowana przez Kamilę Kuros-Kowalską. Jako pierwsi podczas przedostatniego panelu wystąpili Mikołaj Witkowski oraz Dariusz Jakubowski, reprezentujący Uniwersytet Śląski w Katowicach. Temat ich wystąpienia odnosił się do zagadnienia komunikacji w sposób nieco odmienny od pozostałych, głównym bowiem przedmiotem zainteresowania prelegentów było porozumiewanie się z przedstawicielami odmiennej kultury $w$ języku obcym oraz niekonwencjonalne sposoby jego przyswajania, co zostało wskazane $w$ tytule - Wykorzystanie piosenek $w$ dydaktyce języka arabskiego ewaluacja studencka. Jak wykazywali prelegenci, takie niestandardowe metody nauczania oraz wykorzystanie kreatywności w tym procesie może wywierać nań bardzo pozytywny wpływ. Dodatkowo przybliżyli oni słuchaczom nieco szerzej kwestię nauki i użycia języka arabskiego - jak się okazuje, znacznie skomplikowaną ze względu na występowanie dużej liczby dialektów, których przyswojenie wymaga dobrej znajomości kontekstu społecznego i kulturowego. Jako druga podczas sesji wystąpiła Katarzyna Węsierska, związana z Uniwersytetem Śląskim oraz Centrum Logopedycznym w Katowicach. Swoje wystąpienie poświęciła zagadnieniu udzielania wsparcia dziecku jąkającemu się, ze zwróceniem szczególnej uwagi na niezwykle istotnych uczestników tego procesu - jego rodziców. Po przybliżeniu audytorium opinii osób jąkających się, dotyczących tego, jakiego wsparcia potrzebują i oczekują od najbliższego otoczenia, prelegentka przedstawiła wyniki badania przeprowadzonego wśród amerykańskich i polskich rodziców dzieci z zaburzeniami płynności mowy. W badaniu sondowano opinie ekspertów na temat najmniej oraz najbardziej wspierających zachowań i osób lub grup. Jego wyniki wykazały zarówno wiele punktów wspólnych, jak i różnic w opiniach rodziców z Polski i Stanów Zjednoczonych. Jako ostatnia wystąpiła Agnieszka Płusajska-Otto, związana z łódzką Państwową Wyższą Szkołą Filmową, Telewizyjną i Teatralną. Jej prezentacja, nosząca tytuł O komunikacji interpersonalnej, czyli jak być słyszanym, rozumianym i chętnie słuchanym. Refleksje studentów Szkoły Filmowej $w$ Łodzi, tym razem dotyczyła komunikacji nie tylko jako procesu, międzyludzkiej wymiany myśli i odczuć, lecz głównie jej widocznego i odczuwalnego aspektu - doskonalenia poprawnej artykulacji i emisji, ze zwróceniem szczególnej uwagi na funkcje z nimi związane, takie jak właściwa postawa ciała. Dodatkowo wystąpienie to od pozostałych wyraźnie odróżniał jego warsztatowy charakter. Tym razem audytorium zostało wprowadzone $w$ tajniki właściwej emisji głosu oraz pracy z nim i nad nim, a także technik oddechowych i relaksacyjnych. 
Po tym wystąpieniu zakończyła się główna część konferencyjna i rozpoczęła się kolejna, równie istotna część wydarzenia. Podczas jej trwania miało miejsce szczególne wydarzenie polska premiera filmu Johna Gomeza When I Stutter - Kiedy się jakam. Jest to nieco ponadgodzinny materiał o dokumentalnym charakterze, w ramach którego jąkający się: kobiety i mężczyźni dzielą się swoimi doświadczeniami, opowiadają o wyzwaniach i ograniczeniach, związanych z towarzyszącą im niepłynnością mowy. Co niezwykle wartościowe, film ten daje widzowi możliwość faktycznego identyfikowana się z bohaterami i wczucia w ich sytuację oraz wrażenia dzięki wizualizacjom towarzyszącym ich historiom. Dodatkowo po zakończeniu projekcji uczestnicy wydarzenia mieli możliwość wzięcia udziału w wywiadzie $z$ twórcami filmu. Wywiad ten prowadzony był w czasie rzeczywistym, z wykorzystaniem komunikatora Skype, dzięki czemu nie tylko prowadzący, wymienieni wyżej moderatorzy panelu, lecz także obecni na sali mogli uzyskać odpowiedzi na nurtujące ich pytania.

Był to ostatni z zaplanowanych elementów konferencji „Dialog bez barier”, po którego zakończeniu organizatorki wydarzenia - Katarzyna Węsierska, Ewa Ficek oraz Kamila Kuros-Kowalska - dokonały oficjalnego podsumowania, dziękując aktywnym uczestnikom oraz zebranym słuchaczom i tym samym zamykając to wyjątkowe wydarzenie, które spotkało się z pozytywnym odbiorem osób biorących w nim udział. Za szczególne walory i wartości konferencji należy uznać przede wszystkim zróżnicowanie wystąpień, zarówno ze względu na ich formę, bo choć znaczna część z nich miała charakter badawczy, znalazły się wśród nich także prelekcje zawierające elementy warsztatowe, jak i ze względu na treść. Choć tematy oraz główne przedmioty zainteresowania poszczególnych prezentacji znacznie różniły się od siebie, wciąż najistotniejszą kwestią pozostawała komunikacja i dialog, a punktem wspólnym różnych ujęć tych zagadnień był wyraźny cel - dążenie do lepszej, bardziej otwartej, skuteczniejszej komunikacji z drugim człowiekiem. 